Crop Breeding and Applied Biotechnology 12: 118-125, 2012

Brazilian Society of Plant Breeding. Printed in Brazil

\title{
ARTICLE
}

\section{Identification of a Simple Sequence Repeat molecular-marker set for large-scale analyses of pear germplasm}

Gabriel Dequigiovanni ${ }^{1}$, Fernanda Rech ${ }^{1}$, Felippe George Gatti Gomes ${ }^{1}$, Ivan Somensi Cerotti ${ }^{1}$, Ivan Faoro ${ }^{2}$, Paulo Ricardo Dias de Oliveira ${ }^{1}$, Vera Quecini and Patricia Ritschel ${ }^{1 *}$

Received 11 October 2011

Accepted 20 April 2012

\begin{abstract}
Simple Sequence Repeats (SSR) are molecular markers suitable to assess the genetic variation of germplasm resources; however, large-scale SSR use requires protocol optimization. The present work aimed to identify SSR markers, developed for pear and other fruit species that are effective in characterizing pear germplasm collections and in demonstrating their use in providing support for genetic breeding programs. From a total of 62 SSR markers investigated, 23 yielding reproducible and polymorphic patterns were used to genotype a sample of 42 pear accessions of the Brazilian Pear Germplasm Bank (PGB). When compared to these 23 SSR markers, a subset of eleven markers, selected based on He, PIC and PId, was used to distinguish individual accessions and perform cluster analysis with similar efficacy. Genetic diversity analysis clustered the European, Japanese and Chinese accessions in distinct groups. This markers subset constitutes a valuable tool for several applications related to pear genetic resources management and breeding.
\end{abstract}

Key words: Pyrus sp., microsatellites, genetic resources, genetic diversity.

\section{INTRODUCTION}

The genus Pyrus consists of 22 species originated in Europe, temperate regions in Asia and high-altitude locations in Africa, along with six natural interspecific hybrids. Among them, $P$. communis and $P$. pyrifolia are the most disseminated species, whereas $P$. ussuriensis and $P$. $\mathrm{x}$ bretschneideri are important for specific areas (Bell and Itai 2011). In 2009, pear was one of the ten most produced fruit crops worldwide, and in Brazil it ranks first in the imported fruits list (FAO 2011, IBRAF 2011). One of the factors contributing to the low pear yields in the country is the lack of cultivars adapted to soil and climate conditions of the main growing areas in Southern Brazil.

The success of pear breeding programs relies on the support of organized germplasm banks, consisting of wellcharacterized genetic material that displays variation for the traits of interest (Gepts 2006). Therefore, along with the reestablishment of the pear breeding program in Brazil, several approaches to organize, characterize and expand the Pear Germplasm Bank (PGB) are currently being car- ried out (Oliveira et al. 2010). The core collection of the PGB is maintained ex situ in the field by EPAGRI, Santa Catarina State, and consists of approximately 200 accessions. Smaller collections are also maintained by Embrapa Grape and Wine, Rio Grande do Sul State. One of these collections consists of 27 accessions maintained in the field and another, with approximately 40 accessions, has been introduced from the USA main collection, and is currently being propagated by grafting.

The molecular characterization of plant germplasm provides valuable information to identify duplicated and divergent accessions for breeding and collection-enrichment purposes, especially when analyzed together with morphological data. Several types of molecular markers can be used to estimate the genetic diversity of germplasm bank accessions (Karp at al. 1997). In pear, a wide range of molecular markers has already been used for numerous purposes, including genetic diversity studies (Chevreau et al. 1997, Sawazaki et al. 2001, Bao et al. 2007, Ritschel et al. 2008, Cai et al. 2010).

\footnotetext{
${ }^{1}$ Embrapa Uva e Vinho, Rua Livramento, 515, C.P. 130, 95.700-000, Bento Gonçalves, RS, Brazil. *E-mail: patricia@cnpuv.embrapa.br

2 EPAGRI, Estação Experimental de Caçador, C.P. 591, 89.500-000, Caçador, SC, Brazil
} 
Among the markers used in pear studies, Simple Sequence Repeats (SSR) consist in sets of specific primers employed to amplify genomic regions characterized by short motifs of tandem DNA repeats. These markers are frequently multiallelic and exhibit co-dominant segregation (Litt and Luty 1989). Due to their highly polymorphic content and wide genome coverage, SSR markers are often used in the genetic characterization of germplasm banks (Powell et al. 1996, Karp at al. 1997).

The objective of the present work was to identify SSR molecular markers, developed for pear and other fruit species, which are effective to genetically characterize pear plant accessions using standard DNA extraction and PCR amplification conditions, in order to allow medium- and large-scale analysis without major protocol adaptations. The identified markers were used to genetically characterize a sample of 42 accessions from the PGB. Genetic data analysis indicated a representative and effective subset of SSR markers to distinguish individual accessions and to perform cluster analysis with similar efficacy to the major set, and that are able to allow the organization of the Pyrus genetic resources in Brazil and to provide support to breeding programs.

\section{MATERIAL AND METHODS}

\section{Genetic analysis}

Forty-two accessions of the PGB were selected to compose a representative sample, including European ( $P$. communis) and Asian (Japanese P. pyrifolia and Chinese $P$. ussuriensis) cultivars, interspecific hybrids and accessions of unknown origin. Young leaves were collected from one individual plant of each accession. DNA was isolated as described by Doyle and Doyle (1990) and quantified by standard procedures.

The analysis employed 62 SSR markers developed for several fruit species: cherry (one), peach (five), apple (14) and pear (42), which have been previously tested in pear materials (Yamamoto et al. 2001, Yamamoto et al. 2002a, Yamamoto et al. 2002b, Yamamoto et al. $2002 c)$. Although it had already been tested in pear, the performance of the SSR markers under local conditions of DNA extraction and PCR amplification was verified to allow medium- and large-scale genotyping. A sub-sample consisting of six pear accessions ('Williams', 'Packhams', 'Kieffer', 'Carrick', 'Njisseiki' and 'Machiro') was used to investigate the amplification profile of the SSR loci and adjust the annealing temperature for each primer pair.
The SSR loci were genotyped by PCR amplifications carried out in a final volume of $13 \mu \mathrm{L}$, containing DMSO (5\%), dNTP $(0.25 \mathrm{mM}$ of each nucleotide), primer pair $(0.3 \mu \mathrm{M})$, Tris $\mathrm{HCl}(10 \mathrm{mM} \mathrm{pH} 9.0), \mathrm{MgCl}_{2}(1.5 \mathrm{mM}), \mathrm{Taq}$ polymerase $(1 \mathrm{U})$ and $7.5 \mathrm{ng}$ of DNA. The amplification conditions were as follows: $94^{\circ} \mathrm{C}$ for 4 minutes, 29 cycles at $94{ }^{\circ} \mathrm{C}$ for 1 minute, $50-58{ }^{\circ} \mathrm{C}$ (depending on the primer pair) for 1 minute, $72{ }^{\circ} \mathrm{C}$ for 1 minute, and a final extension step at $72{ }^{\circ} \mathrm{C}$ for 7 minutes. The reactions were performed using a MJ Research thermocycler PTC 100 equipment.

Amplification products were resolved on denaturing $6 \%$ polyacrylamyde gel with $7 \mathrm{M}$ urea in TBE $1 \mathrm{X}$, with the dimensions of $20 \mathrm{~cm} \times 34 \mathrm{~cm} \times 0.4 \mathrm{~mm}$. Electrophoresis was carried out at constant potency of 45 Watts and the fragments were visualized by silver staining. The alleles at the selected loci were identified by the molecular weight, estimated by the number of base pairs in comparison to the size of commercial standards.

\section{Statistical analysis}

Allele frequencies for the distinct loci were estimated using the software GDA-Genetic Data Analysis (Lewis and Zaykin 2011). A database of allelic frequencies for 23 polymorphic loci genotyped in 42 pear accessions was obtained. Observed (Ho) and expected (He) heterozygosity and genetic parameters, such as allele size range and number of alleles were also estimated for each SSR locus. The percentage of Ho was calculated as the ratio between the number of heterozygous individuals and the total number of individuals per locus. He was estimated based on the probability of two randomly chosen individuals in the same sample that exhibited distinct alleles for a given locus (Nei 1987). PIC ("Polymorphism Information Content") was estimated based on the probability of an informative individual in relation to the segregation of its inherited alleles (Botstein et al. 1980).

In order to identify a subset of markers that are able to distinguish individual accessions and perform cluster analysis with similar efficacy as the whole set of markers, estimates of individual and combined Probabilities of Identity (PId) were computed. The markers were first ranked based on highest values of PIC, He and individual PId. The Probability of Identity (PId), expressed as the probability of a second individual having the same genotype, given the genotype of one individual, was computed as PId $=\sum \mathrm{p}_{\mathrm{i}}^{4}+\sum\left(2 \mathrm{p}_{\mathrm{i}} \mathrm{p}_{\mathrm{j}}\right)^{2}$ (Sefc et al. 1999). Combined PId values for markers selected at random from the whole dataset were then estimated using the resampling procedure (bootstrapping) of the Excel add-in Resampling 
Stats v.3.0 software (Resampling Stats 2006). A subset of SSR loci was selected to estimate the potential of the chosen markers to distinguish the pear accessions and to cluster them according their European, Japanese or Chinese origin.

Genetic similarities between pear accessions, based on the polymorphism of SSR markers, were estimated by the band coefficient (Lynch 1990). The estimates were based on the sum of the proportion of common alleles between two pear accessions divided by the doubled number of tested loci (Lynch 1990, Bowcock et al. 1994, Goldstein et al 1995). Genetic distances were obtained using the software NTSYS 2.02 (Rohlf 1992). The diagonal matrix was used for clustering analysis by UPGMA and allowed the construction of a dendrogram (Rohlf 1992). Clustering analysis was carried out considering the whole marker dataset and the subset of selected markers. The comparison between the dendrograms generated with the whole dataset or the subset of SSR loci was performed by Spearman's rank correlation analysis of the genetic distance matrices and by $\mathrm{K}$ tree score, a method that measures overall differences in the relative branch length and topology of two phylogenetic trees (Soria-Carrasco et al. 2007).

\section{RESULTS AND DISCUSSION}

\section{SSR marker selection}

Since the present work aims to identify SSR markers for middle to large scale analysis of pear germplasm, the conditions of DNA extraction and PCR amplification were kept constant throughout the experiment, varying only the annealing temperature for specific primer pairs. The markers were used to genotype a sub-sample of six pear accessions. The failure to amplify alleles at a number of previously characterized SSR markers indicated that the conditions used in the present work are not suitable for some of them. In the process of selecting SSR markers to genetically characterize the PGB, polymorphism level along with amplification stability and reproducibility were used as major selection criteria.

Under the conditions used in the present work, makers developed for cherry and peach were not successfully transferable to genotype pear accessions. In contrast, fragments were successfully amplified in pear DNA for $50 \%$ of the markers developed for apple and $70 \%$ of the markers originally designed to genotype pear accessions. A set of 23 polymorphic and reproducible SSR markers was selected out of the 62 markers originally tested (CH01B12,
CH01H01, CH02B03, CH02D11, CH02F06, CH2B10, KA14, KA16, KA4B, KU10, NB105, NB109A, NB11, NH013, NH021, NH022, NH023A, NH026A, NH027A, NH029, NH030, NZ2814 and RGL1). Loci with NZ and $\mathrm{CH}$ prefixes were transferred from apple to pear, and loci with $\mathrm{KA}, \mathrm{KB}, \mathrm{KA}, \mathrm{KU}, \mathrm{NH}, \mathrm{NB}$ and RGL prefixes were originally developed in pear. All selected markers have been previously used to genotype pear accessions (Yamamoto et al. 2001, Yamamoto et al. 2002a, Yamamoto et al. 2002b, Yamamoto et al. 2002c). The 23 SSR markers were employed to investigate the genetic diversity of 42 accessions from the PGB.

A high level of polymorphism was observed in the analyzed pear sample, as expected for a self-incompatible and allogamous genus, such as Pyrus (Bao et al. 2007). Estimated values of Ho were high for most marker loci, with the exception of KA14, NHO3 and NB109A. The number of alleles per locus ranged from 3 (KA14) to 11 (NH027A, NH021, CH01H01 and NB11). Expected heterogozysity (He) ranged from 0.57 (KA14) to 0.89 ( $\mathrm{CH} 01 \mathrm{H} 01)$, whereas the mean observed heterozygosity was 0.56 . In 13 SSR loci the pear accessions are mainly heterozygous (RGL1, KA14, KU10, KA4B, NH029, NHO30, CH2B10, NB105, NH021, CH01B12, CH01H01, KA16, NB11) and the most common genotype on each locus is also heterozygous. In a similar study investigating several Pyrus sp. samples, the allele size ranged from 3 to 17 and, for P. pyrifolia, the mean observed heterozygosity was 0.69 , whereas the mean expected heterozygosity was 0.71 (Yamamoto et al. 2001, Yamamoto et al. 2002a, Yamamoto et al. 2002b). The polymorphism of SSR markers developed for $P$. communis was variable and the number of alleles per locus ranged from 2 to 18 , the observed heterozygosity, from 0.25 to 0.91 , and the expected, from 0.30 to 0.95 (Fernández-Fernández et al. 2006). In another experiment, the employment of six SSR markers developed for apple in a sample of 63 European pear accessions resulted in a mean number of alleles per locus of 6.6 and mean expected and observed heterozygosities of 0.68 and 0.44 , respectively (Wünsch and Hormaza 2007).

Polymorphism Information Content (PIC) was estimated for 23 markers, with values ranging from 0.48 (KA14) and 0.87 (CH01H01). A subset of these markers may be used to provide the genetic identification of pear accessions, for applications such as identity test, paternity test, vegetative plant production, cultivar protection and germplasm genetic characterization. 
Based on individual estimates of PIC, PId and Ho, and on combined PId groups of increasing number of markers, it was observed that a subset of 11 markers, selected out of the whole dataset, could be used to distinguish individual accessions and perform cluster analysis with similar efficacy as the whole set of markers (Table 1). Estimates of combined PId for the subset was $2.4610^{-16}$, indicating that the subset of 11 markers can be efficiently used to differentiate pear accessions. The subset was used to further investigate the sample of 42 accessions from the PGB according to their origin: "European", "Japanese" or "Chinese". The estimated PId of the marker subset considering only "European" pears was $1.9510^{-14}$, while the PId for the "Japanese" pears was $1.3610^{-9}$ (Figure 2).

Table 1. Genetic characterization of the 11 selected SSR markers

\begin{tabular}{lccccc}
\hline Locus & TA $^{\mathbf{1}}$ & $\begin{array}{c}\text { Allele } \\
\text { Number }\end{array}$ & $\mathbf{H e}^{2}$ & $\mathbf{H o}^{\mathbf{3}}$ & PIC $^{4}$ \\
\hline CH01H01 & 54 & 11 & 0.89 & 0.93 & 0.87 \\
\hline CH02B03 & 54 & 9 & 0.81 & 0.46 & 0.76 \\
\hline NH021 & 56 & 11 & 0.86 & 0.71 & 0.71 \\
\hline NH023A & 56 & 6 & 0.75 & 0.44 & 0.71 \\
\hline RGL1 & 52 & 7 & 0.80 & 0.73 & 0.75 \\
\hline NB105 & 56 & 10 & 0.88 & 0.93 & 0.86 \\
\hline NH027A & 56 & 11 & 0.79 & 0.31 & 0.75 \\
\hline NH029 & 52 & 7 & 0.83 & 0.71 & 0.80 \\
\hline NH030 & 52 & 9 & 0.82 & 0.65 & 0.78 \\
\hline NZ2814 & 52 & 6 & 0.78 & 0.41 & 0.73 \\
\hline
\end{tabular}

${ }^{1}$ Annealing temperature in ${ }^{\circ} \mathrm{C}$

${ }^{2}$ Expected heterozygosity

${ }^{3}$ Observed heterozygosity

${ }^{4}$ Polymorphism Information Content

\section{Genetic similarities between PGB accessions}

The results of the analysis of SSR gel allowed the construction of two diagonal matrices, obtained from 23 (whole dataset) and 11 loci (subset), which resulted in similar dendrograms, both displaying distinct clusters for "European", "Japanese" and "Chinese" accessions (Figure 2). Moreover, Spearman's rank correlation coefficient between the genetic diversity matrices accessed by 23 and 11 SSR loci was 0.9367 and the K score between the generated dendrograms was 0.557 , indicating similar topology and branch length variation.

Band coefficient of similarity values ranged from 0.09 to 1.00. Values close to 1.0 represent very similar genotypes, considering the group of markers employed. The results of the SSR analysis reflect the botanical classification and the genomic context of the accessions investigated. Thus, three main clusters were formed, consisting of "European pears", "Japanese pears" and "Chinese pears".

\section{European pears}

This group includes accessions classified as $P$. communis. The information on the origin and genealogy was obtained from Hedrick (1921), Delbard (1947), Campo-Dall'orto et al. (1996) and from the USA germplasm information bank GRIN (USDA-ARS 2011). One subgroup is composed of five accessions associated to the traditional British cultivar 'Bon Chrétien Williams', originated in 1770 and propagated under the abbreviation of Williams. The denomination was lost during the introduction of the material in the United States, around 1799, where it became known as 'Bartlett', named after the owner of the nursery that propagated the material in the country. In the dendrogram (Figure 2), three accessions with identical genotype are found (band coefficient $=1.00)$. The accessions 'Williams' and 'Bartlett' correspond to the European cultivar "Bon Chrétien Williams" and were introduced in the PGB at different moments, with the American and European denominations, thus, representing duplicates. The estimated value of PId for the common genotype of Bartlett and Williams is 1.49 $10^{-12}$. The third material in the cluster is the cultivar Max Red Bartlett, described as a somatic mutation of 'Bon Chrétien Williams'. Although the common name may suggest that 'Winter Bartlett' also represents a mutation of the previous cultivar, it is probably originated from seeded plants of 'Bon Chrétien Williams', around 1880. Its similarity to other pears from the Bartlett group and the results from the present work support this hypothesis. The fifth accession in the cluster, 'Packhams Triumph', was selected in Australia in 1886-7, from a cross between 'Uvedale St. Germain' and 'Bon Chrétien Williams'.

The other seven accessions included in the "European" cluster are also cultivars originated from Europe. Six accessions were originated in France during the $18^{\text {th }}$ and $19^{\text {th }}$ centuries. The exception is 'Clapp's Favorite', which resulted from a cross, carried out in the United States, between 'Flemish Beauty', derived from a seedling from a plant found in Belgium in the beginning of the $19^{\text {th }}$ century, and 'Bartlett'. 'Curé' was identified by a French farmer as a plant of natural occurrence in the region of Villiers-en-Brenne. Subsequently, it was introduced in England by the vicar of Winkfield, from whom its current name is derived ('Vicar of Winkfield'). 'Beurre Rose' is described in the literature as a French cultivar, although its genealogy is not known. 'Passe Crassane' was selected from a sample of seedlings in Rouen, around 1845. 'Beurre d'Anjou' is probably originated from the region of Angers and it was introduced in England and in the United States in the $19^{\text {th }}$ century. 'Abate Fetel' was originated in France, in 1866, and its genealogy is also not known. 'Beurre Hardy' is a French pear, selected around 


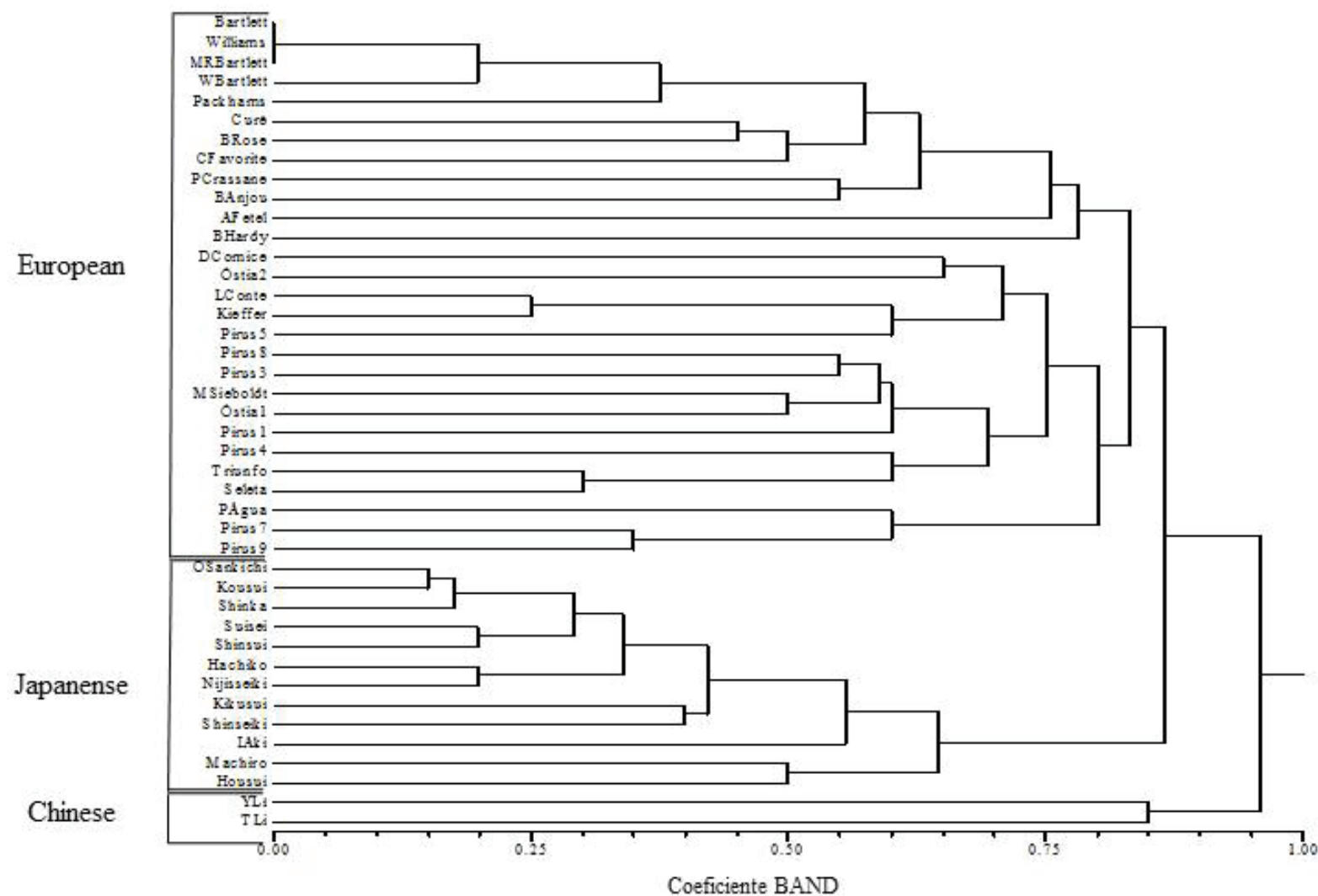

Figure 2. UPGMA based cluster analysis of 42 accessions of the Brazilian Pear Germplasm Bank genotyped with a panel of eleven SSR markers.

1820 , in the region of Boulogne-sur-Mer. After 1840, it was propagated by a nursery in Paris, which labeled it after M. Hardy, director of the Luxembourg Botanical Garden. 'Doyenne du Comice', which was selected as a seedling at the "Comice Horticule" in Angers in 1849, clustered with hybrids and pears from unknown origin, indicating the presence of non-European ancestry.

A sub-cluster within the "European" group consists of accessions of hybrid nature, such as 'Le Conte', 'Kiefer' (P. communis $x$ P. pyrifolia) (USDA-ARS 2011), 'Triunfo' and 'Seleta' [P. communis $x$ (P. communis $x$ P. pyrifolia)] (Campo-Dall'orto et al. 1996, Sawasaki et al. 2001), and the material of unknown origin and/or genealogy. The position of the sub-cluster in the dendrogram suggests that they exhibit distinct proportions of European and Asian germplasm, with a predominance of those of European origin. Some accessions seem to have a higher contribution of European genome compared to Asian genomes, such as the cultivars 'Triunfo' and 'Seleta', released by Instituto Agronômico de Campinas, Brazil. The genealogy of the accessions 'Madame Sieboldt', 'Óstia 1' and 'Óstia 2' and of the series 'Pirus' is unknown. The accessions labeled 'Óstia 1' and 'Óstia 2' constitute distinct entries in the PGB and were thought to represent duplicates. The distinct genetic profiles of both material named 'Óstia' indicate that they actually represent distinct accessions (Figures 1 and 2).

\section{Japanese pears}

This cluster groups the Japanese pears, classified as $P$. pyrifolia, along with two accessions of unknown classification. The information on the genealogy and origin were recovered from Sawamura et al. (2004), Campo-Dall'orto et al. (1996) and from the GRIN database (USDA-ARS 2011). The accessions were closely clustered in the group, what could be explained by their ancestry. Except for 'Okusankishi', 'Nijisseiki' and 'Imamura Aki', which are old cultivars, almost all accessions of Japanese pears in the sample are related to the cultivar 'Nijisseiki'.

'Okusankishi' is an old Japanese cultivar, originated from a seedling from the cultivar 'Wasesankichi', discovered in the city of Niigata. 'Nijisseiki', or ' $20^{\text {th }}$ Century', in English, and 'Imamura Aki', were selected from seed samples of unknown origin, in the district of Matsudo, in 1888, and in the region of Takoaka, Kochi district, in Japan, respectively. 


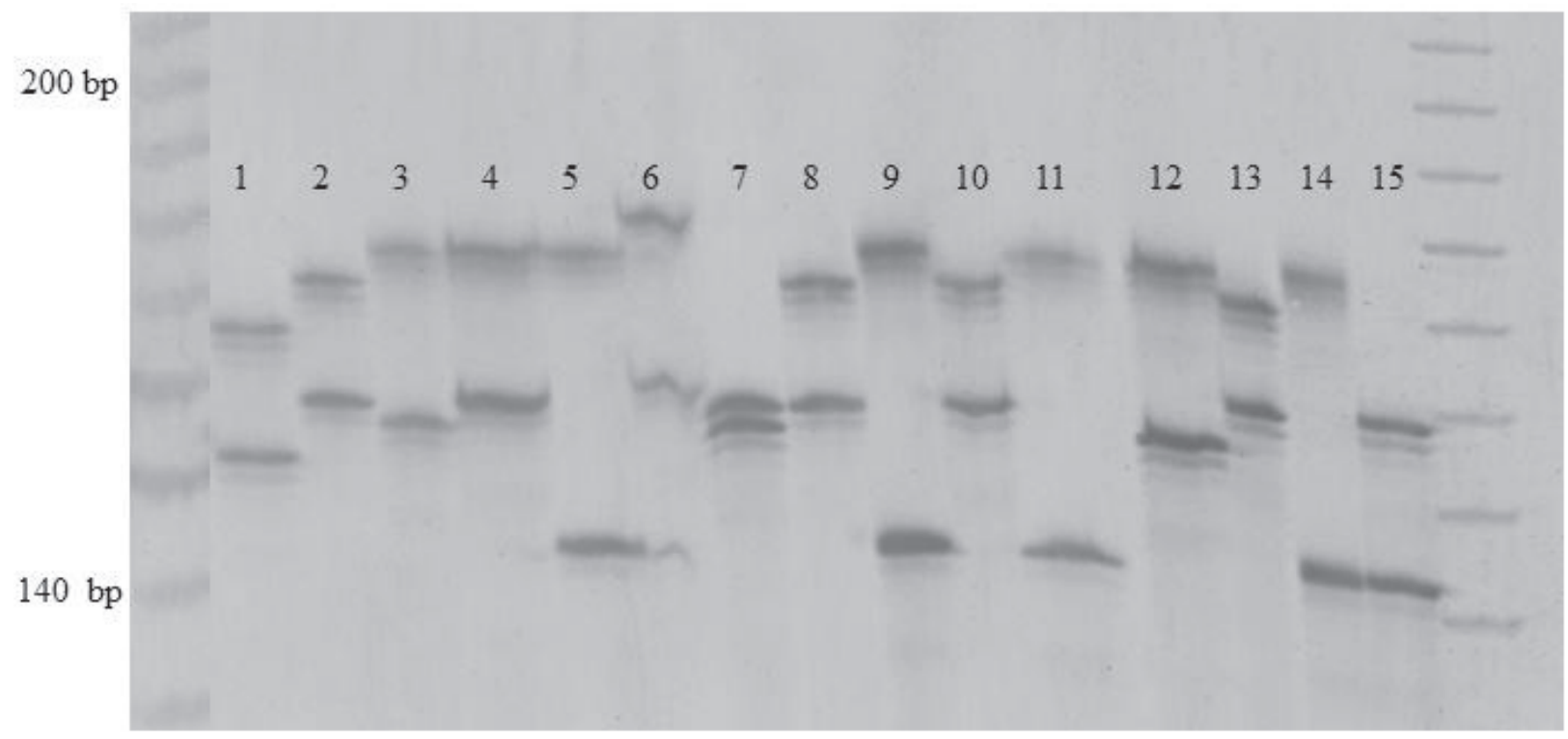

Figure 1. Size variation of the marker SSR NB105 in accessions of the Pear Germplasm Bank (PGB) visualized on silver-stained denaturing polyacrylamide gel. Accession names and fragment sizes in base pairs (beetween brackets): 1: Ya-li (165/150); 2: Tsu-li (170/160); 3: Pirus 8 (180/155); 4: Pirus 3 (180/160); 5: Pirus 1 (180/145); 6: Pirus 4 (185/165); 7: Pirus 5 (160/155); 8: Triunfo (170/160); 9: Madam Sieboldt (180/145); 10:Seleta (170/160); 11: Óstia 1 (175/145); 12: Óstia 2 (180/155); 13: Pera D’água (170/160); 14: Pirus 7 (175/140); 15: Pirus 9 (160/140).

The majority of the remaining accessions were obtained by the Japanese pear breeding program from crosses in the 1940-50, with exception of 'Shiko', originated from a seedling of 'Nijisseiki'. Crosses employing the pear material Kikusui ('Taihaku' X 'Nijisseiki') originated the cultivar 'Kousui' ('Kikusui' X 'Wasekozo'), in 1941; the cultivar 'Suisei' ('Kikusui' X 'Yakumo'), in 1955; the cultivar 'Shinsui' ('Kikusui' X 'Kimizukawase'), in 1947; and the cultivar 'Housui' ['Kikusui' X ('Ishiiwasi' X 'Nijisseiki')], in 1954. 'Shinseiki' or 'New Century', in English, resulted from the cross between 'Nijisseiki' and 'Chojuro', in 1945, in the region of Okayama. 'Hachiko' and 'Machiro', two accessions that produce the Eastern-type of fruits and of unknown classification, origin and genealogy, were clustered to the Japanese group.

\section{Chinese pears}

The Chinese cluster contains the cultivars 'Ya-li' and 'Tsu-li', of uncertain genealogy, belonging to the species P. ussuriensis. 'Ya-li' is an ancient cultivar, common in Northeastern China, whereas 'Tsu-li' has been cultivated in the North of China for centuries (USDA-ARS 2011).

\section{CONCLUSIONS}

Out of 62 SSR markers developed for pears, peaches, apples and cherries, 23 markers are adequate for genetic analysis of pear germplasm, using standard protocol conditions described in the present work.
The selected markers were used to genotype a sample of 42 accessions of the PGB and a database of allele frequency was obtained.

Based on polymorphism, amplification stability and reproducibility criteria, a subset of eleven SSR markers was selected for use in middle to large scale genotyping of pear accessions. The combined Probability of Identity (PId) for eleven markers, expressed as the probability of a second individual having the same genotype, given the genotype of one individual, was estimated as $2.4684 \times 10^{-16}$, indicating that the markers can be efficiently used in genetic analysis of pear genetic resources. The described set of SSR markers, amplification and detection conditions constitute a valuable tool for several applications, such as: identity tests, paternity tests, identification of divergent parents for sexual hybridizations, hybrid nature confirmation in crossing-derived populations, identification of propagated material, cultivar protection and large-scale analysis of pear genetic resources.

The application of the identified marker subset on a representative sample of the PGB allowed the recovery of information on the genetic relationships among the 42 investigated accessions, clustered in three distinct groups: "European" pears (P. communis), "Japanese" pears $(P$. pyrifolia) and "Chinese" pears (P. ussuriensis). The known hybrids and accessions of unknown origin clustered with the "European" pears. 
Identification of a Simple Sequence Repeat molecular-marker set for large-scale analyses of pear germplasm

The genetic characterization resultant from the application of the set of markers identified in the present work is currently contributing to organize and investigate pear genetic resources, maintained in collections in Southern Brazil. Clustering analysis allowed the identification of duplicated entries with distinct names and the estimate of the genetic relationships among accessions of unreliable passport data, identified as the same entry in the Pear Germplasm Bank.

\section{ACKNOWLEDGMENTS}

The work was financed by Embrapa/Macroprograma 1/Plataforma de Recursos Genéticos and Embrapa/Macroprograma 2/Project "Consolidação do programa brasileiro de melhoramento genético da pereira". VQ is recipient of CNPq research grant 307031/2010-1.

\title{
Identificação de um conjunto de marcadores moleculares Simple Sequence Repeats (SSR) para análises em escala de germoplasma de pera
}

\begin{abstract}
Resumo - Simple Sequence Repeats (SSR) são marcadores moleculares adequados para estimar a variação genética de recursos genéticos; no entanto, o uso de SSR em escala requer a otimização de protocolos. Este trabalho objetivou identificar marcadores microssatélites, desenvolvidos para pera e outras espécies de frutas, para caracterizar coleções de germoplasma de pera e demonstrar seu uso em programas de melhoramento. De 62 marcadores investigados, 23 resultando em padrões reproduzíveis e polimórficos foram utilizados para genotipar uma amostra de 42 acessos do Banco Ativo de Germoplasma de Pera. Quando comparado com os 23 marcadores microssatélites, um subconjunto de 11 marcadores, selecionados com base em He, PIC e PId, foi usado para distinguir acessos e realizar a análise de agrupamento com eficácia similar, separando os acessos europeus, japoneses e chineses em grupos distintos. Esse subconjunto de marcadores constitui uma ferramenta útil para aplicações em manejo de recursos genéticos e melhoramento de pera.
\end{abstract}

Palavras-chave: Pyrus sp., microssatélites, recursos genéticos, diversidade genética

\section{REFERENCES}

Bell R and Itai A (2011) Pyrus. In Kole C (ed.) Wild crop relatives: genomic and breeding resources - temperate fruits. Springer, Heidelberg, p. 147-177.

Bao L, Chen K, Zhang D, Cao Y, Yamamoto T and Teng Y (2007) Genetic diversity and similarity of pear (Pyrus L.) cultivars native to East Asia revealed by SSR (simple sequence repeat) markers. Genetic Resources and Crop Evolution 54: 959-971.

Botstein D, White RL, Skolnick M and Davis RW (1980) Construction of a genetic linkage map in man using restriction fragment polymorphisms. The American Journal of Human Genetics 32: 314-331.

Bowcock AM, Ruiz-Linhares A, Tomfohrde J, Minch E, Kidd JR and Cavalli-Sforza LL (1994) High resolution of human evolutionary trees with polymorphic microsatellites. Nature 368: 455-457.

Cai D, Zheng X, Teng Y and Spooner DM (2010) Genetic relationships among Pyrus pyrifolia cultivars from southeastern China and Japan. Acta Horticulturae 859: 89-92

Campo-Dall'orto FA, Ojima M, Barbosa W, Rigitano O, Martins FP, Castro JL, Santos RR and Sabino JC (1996) Variedades de pera para o estado de São Paulo. Instituto Agronômico, Campinas, 34p.

Chevreau E, Leuliette S and Gallet M (1997) Inheritance and linkage of isozyme loci in pear (Pyrus communis L.). Theoretical and Applied Genetics 94: 498-506.

Delbard G (1947) Les beaux fruits de France. Editions George Delbard, Paris, 164p.
Doyle JJ and Doyle JL (1990) Isolation of plant DNA from fresh tissue. Focus 12: 13-15.

FAO (2011) Statistical Databases - FAOSTAT. Available at $<$ http//apps.fao. org/page/ collections?subset=agriculture $>$ Assessed on abr. 27, 2011.

Fernández-Fernández F, Harvey NG and James CM (2006) Isolation and characterization of polymorphic microsatellite markers from European pear (Pyrus communis L.). Molecular Ecology Notes 6: 1039-1041.

Gepts P (2006) Plant genetic resources conservation and utilization: the accomplishments and future of a societal insurance policy. Crop Science 46: 2278-2292.

Goldstein DB, Ruiz Linares A, Cavalli-Sforza LL and Feldman MW (1995) Genetic absolute dating based on microsatellite and the origin of modern humans. Proceedings of the National Academy of Sciences of the United States of America 92: 6723-6727.

Hedrick UP (1921) The pears of New York. J. B. Lyon Company, Albany, 828p.

IBRAF - Instituto Brasileiro de Frutas (2011) Available at <http://www. ibraf.org.br> Assessed on abr. 27, 2011.

Karp A, Kresovich S, Bhat KV, Ayad WG and Hodgkin T (1997) Molecular tools in plant genetic resources conservation: a guide to the technologies. Bioversity International, Rome, $47 \mathrm{p}$.

Lewis PO and Zaykin D (2011) Genetic data analysis: computer program for the analysis of allelic data. Version 1.0 (d16c). Available at http:// lewis.eeb.uconn.edu/lewishome/software.htm. Assessed on June 7, 2011. 
Litt M and Luty JA (1989) A hypervariable microsatellite revealed by in vitro amplification of a dinucleotide repeat within the cardiac muscle actin gene. The American Journal of Human Genetics 44: 397-401.

Lynch M (1990) The similarity index and DNA fingerprinting. Molecular Biology Evolution 7: 478-484

Nei M (1987) Molecular evolutionary genetics. Columbia University Press, New York, 284p.

Oliveira PRD, Ritschel PS, Leite GD, Degenhardt JD and Rufato AR (2010) Projetos de pesquisa em melhoramento genético da pereira. In Rufato L (ed.) Reunião técnica da cultura da pereira. 3, Universidade do Estado de Santa Catarina, Lages, p. 64-55.

Powell W, Morgante GB, Andre C, Hanafey M, Vogel J, Tingey S and Rafalski A (1996) The comparison of RFLP, RAPD, AFLP and SSR (microsatellite) markers for germplasm analysis. Molecular Breeding 2: 225-238.

Reasamplig Stats (2006) Available at < http://www.resample.com/content/ about.shtml $>$ Assessed on Jun. 29, 2006.

Ritschel P, Revers LF, Oliveira PRD, Leite GB and Ferreira ME (2008) Genetic analysis of accessions in a pear germplasm bank. Acta Horticulturae 800: 409-416.

Rohlf FJ (1992) NTSYS-PC: numerical taxonomy and multivariate analysis system - version 1.7. Exeter Software, New York.

Sawamura Y, Saito T, Takada N, Yamamoto T, Kimura T, Hayashi T and Kotobuki K (2004) Identification of parentage of Japanese pear 'Housui'. Japanese Society of Horticultural Science 73: 511-518.

Sawazaki HE, Barbosa W and Colombo CA (2001) Caracterização e identificação de cultivares e seleções de pereiras através de marcadores RAPD. Revista Brasileira de Fruticultura 24: 447-452.
Sefc KM, Regner F, Turetschek E, Glössl J and Steinkellner H (1999) Identification of microsatellite sequences in Vitis riparia and their applicability for genotyping of different Vitis species. Genome 42: 367-373.

Soria-Carrasco V, Talavera G, Igea J and Castresana J (2007) The K tree score: quantification of differences in the relative branch length and topology of phylogenetic trees. Bioinformatics 23: 2954-2956.

USDA-ARS (2011) GRIN - Germplasm resources information network: accession areas queries. Available at <http://www.ars-grin.gov/npgs/ acc/acc_queries.html > Assessed on June 29, 2011.

Wünsch A and Hormaza JI (2007) Characterization of variability and genetic similarity of European pear using microsatellite loci developed in apple. Scientia Horticulturae 113: 37-43.

Yamamoto T, Kimura T, Sawamura Y, Kotobuki K, Ban Y, Hayashi T and Matsuta N (2001) SSRs isolated from apple can identify polymorphism and genetic diversity in pear. Theoretical and Applied Genetics 102: 865-870.

Yamamoto T, Kimura T, Sawamura Y, Manabe T, Kotobuki K, Hayashi T, Ban Y and Matsuta N (2002a) Simple sequence repeats for genetic analysis in pear. Euphytica 124: 129-137.

Yamamoto T, Kimura T, Shoda M, Imai T, Saito T, Sawamura Y, Kotobuki K, Hayashi T and Matsuta N (2002b) Genetic linkage maps constructed by using an interspecific cross between Japanese and European pears. Theoretical and Applied Genetics 106: 9-18.

Yamamoto T, Mochida K, Imai T, Shi YZ, Ogiwara I and Hayashi T (2002c) Microsatellite markers in peach [Prunus persica (L.) Batsch] derived from an enriched genomic and cDNA libraries. Molecular Ecology Notes 2: 298-301. 